\title{
AN EXPERIMENTAL MODELLING OF STEEL SURFACES WEAR IN INJECION MANUFACTURING OF PLASICS MATERIALS WITH SGF
}

\author{
Lucian Capitanu $^{1}$, Virgil Florescu ${ }^{2}$, Liliana-Laura Badita ${ }^{3}$ \\ ${ }^{1}$ Institute of Solid Mechanics of the Romanian Academy, Bucharest, Romania \\ ${ }^{2}$ Institute of Civil Engineering, Bucharest, Romania \\ ${ }^{3}$ INCD-Mechatronics \& Measurement Technique, Bucharest, Romania
}

\begin{abstract}
Starting from the idea that the greatest pressure and velocity of composite melted is in the die nozzle, was an experimental nozzle with wear samples of sizes and weights which can be measured with precision as good. For a larger accuracy of measurements, we used a method for radiometric measuring, extremely accurate. Different nitriding steels have been studied as nitriding treatments, as well as some special steels and alloyed steels. Besides these, there have been preliminary attempts made to describe and checking corrosive action of termoplastelor on metals.
\end{abstract}

Keywords: Plastics, Composites With Short Glass Fibres, Moulding, Wear, Experimental Modelling, Glass Fibres Content Influence.

\section{INTODUCTION}

Worldwide efforts that are as by appropriate models of tests, should be obtained as much information concerning of the wear mechanisms and their contribution over time, so that the effect can be easily confuted in practice.

In this sense, it differs in three main goals: the choice of alloys and steels resistant to wear and corrosion of machine parts manufacturing; evaluating different plastics depending of their wear action, as well as its physical wear causes. Composite thermoplastic materials are biphasic materials consisting of a mass of polymer and the reinforcement embedded in it. The polymer provides the compressive strength of the material, while the reinforcement improves the tensile strength. Homogeneity of the material and its cohesion has an important role in obtaining some good mechanical characteristics. Thus, the disposal of the reinforcement considerable influences the tensile strength feature.

The elasticity of the polymer can also improve the compression resistance or bending resistance of the reinforcement material. The role of the basic polymer is first of all mechanical and is to provide the bond with the reinforcement fibers. It is the one that transmits the efforts between the reinforcement fibers. Therefore, it is necessary to ensure a minimum adhesion between these two phases.

As a result, in the foreground are two objectives: a verification method and a quantitative evaluation on short term of the wear. Verification method of Deuschen Kunstoff Plastic Institute - DKI in Darmstadt, Germany[1], is a method that can be done in a short time the affirmations about the resistance to wear of various metallic materials, under the action of melted plastic flows with which they come into contact. Of course there is a problem when you want to put into practice these methods of evaluation in a short time. This testing were designed to wear tests close to the practice, with the help of intense collaboration with relevant industries. Thus, the DKI in Darmstadt has done a nozzle of the injection machine, for tests with lamellae test samples, called the "lamellar apparatus". Since verification methods have been described in detail elsewhere, should be further highlighted only the essentials. Plates, metal samples $\left(15_{-} 0.02 / 12^{+0.01} / 5^{+0.01} \mathrm{~mm}\right)$ polished to a roughness $R_{\mathrm{t}}=$ $2.5 \mu \mathrm{m}$, they were mounted by the manner inside the nozzle of an injection machine, that upon exiting the mass processed to form a set of sample with "live corners". The width of this series could be adjusted via a washer. There's a possibility that the material to be injected through an adapter or through a form of injection. By studying the loss of weight of the test plates sample (some up to $\pm 0.05 \mathrm{mg}$ ) could fix easy wear (as weight loss) of the sample. The reproducibility of the measurements is within $\pm 5 \%$. Subsequent checks of surfaces with the electronic microscope and through measurements of roughness, have provided additional information.

A special importance for exact measurement is sign of a cleaning sample test before weighing. Choosing the right cleaning agent for a perfect cleaning of the sample shows some sign of difficulties in thermoplastics, compared to duroplasts, because the metal surface must not be touched when cleaning. The advantages of this method of verification is the following: can highlight simply the geometric shape sign of the sample; the fact that the injection of $10 \mathrm{~kg}$ of plastic with fiber can highlight and as already soon lost weight between 0.5 and $40 \mathrm{mg} / \mathrm{cm}^{2}$, and the possibility of targeted sample sign running back $180^{\circ}$, this can be accomplished two tests. 
In the process of pressing, casting forms provided with cleats can be processed without the appearance of outstanding wear, being provided as corrosive degradation do not exist. In the process of moulding the inevitable wear of plasticizing cylinder and nozzle occurs [2]. It was used as the nozzle to be deemed to be a genuine element of wear and tear and searched as a constructive point of view, the change has to be as easy [3]. If you follow in chronological the wear appearance of plastic processing machines, extruders are to be directed at all the attention. By filling of the moulding forms with thermoplastic materials, parts that can be damaged more or less are barrels and screws, depending on the method of choosing the materials from which they are manufactured, as well as processing procedures. In this case the loosening reason of the components not only appeared through mechanical wear, but due to corrosion. These chronological chases have led specialists to develop a wealth of recipes and types of high temperature resistant alloys, and last but not least to analyse their behaviour to corrosion at high temperatures.

Unfortunately, many of the individual observations of processors and manufacturers of machinery and raw materials were not centralised somewhere, so that numerous discussions in this respect to firms in the processing times in the literature, to recognize that uzurile arising from the active ingredients of plastics processing machines represents a complex problem [4].

Very rarely can identify a unique exact cause of wear, so it is very important to establish and further provided with tools of causality. Wear the solid processing of screws and barrel area of extruders screws and barrels, are the overwhelming of mechanics nature [5]. In most cases it is the erosion of the screw wings. Melting area wear is influenced by the pressure, temperature at which wear is produced, together with the effect of corrosion. Considerably, on this area is very high wear and may result in a few weeks or months to damage of the injection machine. Development and improvement of steels, new finishing methods, as well as lightweight alloys, have resulted in raw materials characterized by high resistance to wear and chemical action.

Wear in the solid processing area of screws of extruders and pistons of injection machines, are the overwhelming nature of mechanics [6]. It is in most cases of erosion on the flanks of the advance of screw. It is in most cases of erosion on the advance flanks of the screw.

Melting area wear is influenced by the pressure, the temperature at which the wear, with the effect of corrosion. In an attempt to determine the resistance to wear of the metal surfaces in contact with the plastic composite flows, reported attempts of modeling through a linear contact between polymer composite with glass fiber on steel surfaces $[7,8,9]$.

Starting from the well known as to be wear, there must be two mandatory conditions: mechanical request (contact pressure) and relative motion between bodies in contact (molten polymer and metal surface), the theoretical modelling has tried contact between molten polymer and metal surfaces of the barrel and screw nozzles (barrel and die).

This modeling, where was approximate the speed to wall of the melted polymer in rheological flow, was presented in detail in [10]. In this way it was possible an estimate of the wear of metal surfaces in contact with the molten polymer feeds [11].

\section{EXPERIMENTAL}

\subsection{Materials}

Were tested four thermoplastics reinforced with glass fibre: Maranyl Polyamide with 20\% SGF [12], Noryl Polyamide with 20\% SGF [13], Nylonplast AVE Polyamide with 30\% SGF [14], Lexan Polycarbonate with $20 \%$ SGF [15] and two unreinforced material, Makrolon Polycarbonate [16], Technyl Polyamide and two allied steels: C120 (steel of similar of 1.8550 steel DIN 17007, or 34 of CrAlNi7 (V) after DIN 17006) and Rp3 (tool steel). Both were tempered steels, resulting in a hardness of $58 \mathrm{HRC}(710 \mathrm{HV})$ for $\mathrm{C} 120$ and $62 \mathrm{HRC}$ (790 HV) for Rp3.

Chemical composition and mechanical properties of these steels have been presented elsewhere [16]. Since these steels can be superficialy hardened through the thin coatings layers of TiN and $\mathrm{CrN}$, have made such wear samples to study the influence of the coating on the wear resistance.

\subsection{Experimental Modelling}

Experimental modeling was inspired by the method of verification in the short term by Deuschen Kunststoff Institut - DKI in Darmstadt [1]. I opted for the design and implementation of a modular experimental nozzles for a mold for injection (Fig. 1). This solution was adopted because it was not possible to amend a nozzle of industrial injection machine, very expensive. In addition, this solution can allow analysis technique of the area with the highest speed and pressure in the injection cycle time. Modularity was necessary because the nozzle to have two samples for wear inside, with little weight, which allows the measurement of wear, with acceptable precision, after a certain number of cycles of injection of plastic materials reinforced with glass fibre.

In Fig. 1 are shown the drawing of the nozzle assembly (figure 1a), a 3D representation of the nozzle (figure 1b) and an expanded representation of the nozzle.

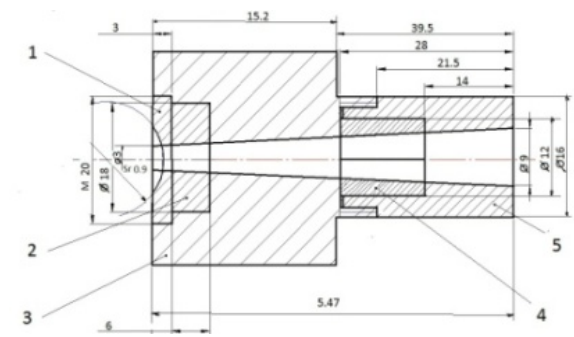

(a) 


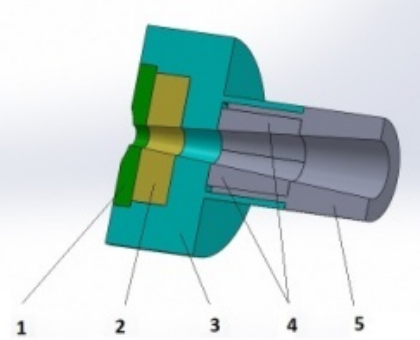

(b)

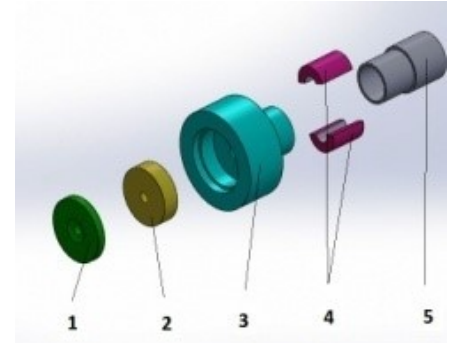

(c)

Fig. - 1: Drawing of the execution of experimental modular nozzle for a mould for injection (a); (b) a 3D representation and (c) an expanded representation, looking parts. Parts 2 and 4 are the wear samples.

This solution was adopted in the idea of some test samples to wear with low weight (positions 2 and 4 in Figs. 1 (a), (b) and (c), which could allow the use of gravimetric measurement method of weight loss.

\section{A. Gravimetric Method}

The initial weight of the samples of each item. pos. 4 in Fig. 1 , is around $1.5-1.6 \mathrm{~g}$ and of the sample and pos. 2 (Fig. 1) is approximately $11.7-11.8 \mathrm{~g}$. The nozzle were made of steel $\mathrm{C} 120$, a steel for moulds, which can be hardened both through hardening (58 HRC), but which can be subjected to tough layer coatings ( $\mathrm{TiN}, \mathrm{CrN})$. The initial weights of wear samples were approximately $11.7 \mathrm{~g}$ (sample 2), respectively 1.5 and $1.6 \mathrm{~g}$ (samples 4).

Gravimetric method used to wear measurement is very close of Deuschen Kunststoff Institut - DKI in Darmstadt [1], except that the wear samples were placed in the mould nozzle, and not die in the nozzle of the barrel, due to the technical difficulties of installation, dismantle and reinstallation of this nozzle on processing machine.

The method consists in measuring the weight difference of wear samples, before and after the injection of a certain quantity of plastics reinforced with a certain percentage of glass short fibers (SGF). Weight measurements were made with an electronic analytical balance, accurate to $\pm 0.01 \mathrm{mg}$. Due to the difficulty of cleaning the nozzle after injection a reinforced plastic reinforced with glass fibre, were executed 5 identical nozzles, one for each of the four plastics reinforced with short glass fibers injected, the fifth nozzle being preserved for possible verification measurements (Fig. 2).

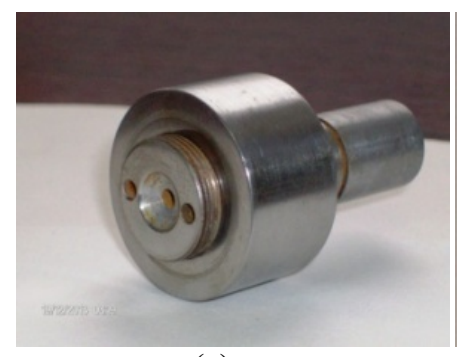

(a)

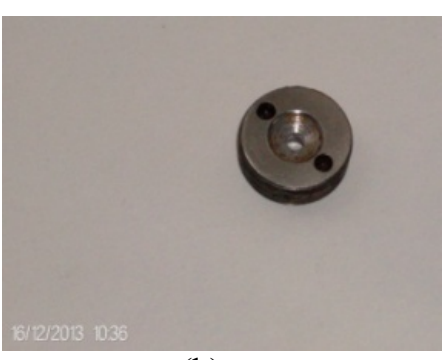

(b)

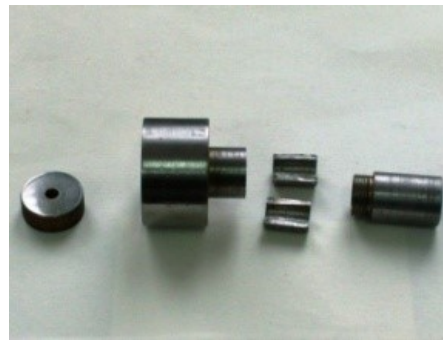

(c)

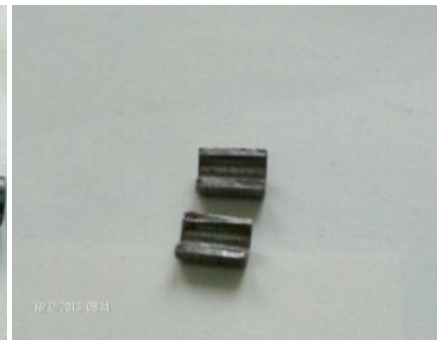

(d)
Fig. -2: The nozzle made of steel C120, after injection of $460 \mathrm{~cm}^{3}$ Nylonplast AVE Polyamide with $30 \%$ SGF. (a)

shows the whole nozzle, after ultrasound cleaning in solvent, (b) the tightening nut (c) a image of the components of the nozzle (d) are presented only of the wear samples.

In injecting a volume of $460 \mathrm{~cm}^{3}$ polyamide reinforced with $30 \% \mathrm{SGF}$, differences in weight (loss of material through wear) of wear samples 4 of figure 1 , were $10-17 \cdot 10^{-5} \mathrm{~g}$. As an example, Fig. 2 shows the images of nozzle made out of C120 steel, used for injecting the has $460 \mathrm{~cm}^{3}$ Nylonplast AVE Polyamide $+30 \%$ SGF, an operation which lasted 18 sec. Detailed results will be presented in further section of results and discussion.

Because weight loss measured gravimetrically are very low and are not excluded and human errors of measurement and interpretation, as well as to the dificulty in perfect cleaning of wear samples, for validation was adopted a method much more expensive, but very precise: radiometric method. Drawing of the execution of experimental modular nozzle for a mold for injection (a); (b) representation of 3D and (c) an expanded representation, looking parts is presented in Fig. 2. Parts 2 and 4 represents the wear samples. Due to costs and the necessary protection measures, the method was applied only for combinations of materials Nylonplast AVE Polyamide $+30 \%$ SGF on C120 and Rp3 steel.

\section{B. Radiometric Method}

Experimental measurement equipment for radiometric method from figure 3 provides the possibility to study the wear behavior also through a radiometric technique, which is extremely accurate.

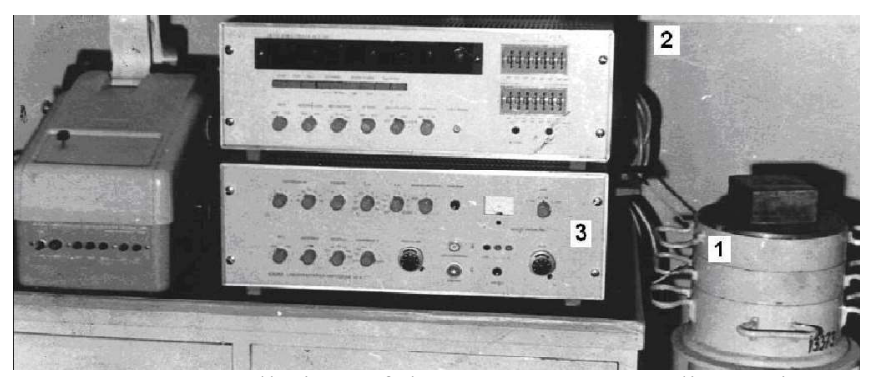

Fig - 3: Overall view of the measurement radiometric device: (1) Pb container with scintillation counter; (2) impulses contor; and (3) data recorder.

The radiometric method consists in superficial irradiation of the metal sample, collection of the wear particles, measurement of its activity and its comparison with the 
activity of a standard weight, irradiated in the same conditions as the metal sample.

Through irradiation, most elements, steel components, react with slow neutrons, in a nuclear reaction that lead to the formation of radioactive isotopes. The specific activity $\Lambda_{\mathrm{i}}$ obtained after time $t$ of irradiation for a certain component element is:

$$
\Lambda_{i}=\Lambda_{\infty}\left(1-e^{\lambda T}\right)
$$

Where $\Lambda_{\mathrm{i}}$ is the limit activity obtained after a long period of irradiation; $\lambda_{\mathrm{i}}$ is the disintegration constant of radioactive isotopes.

Because steels are in fact alloys formed of several elements, their total activity $\Lambda_{0}$ will be:

$$
\Lambda_{0}=\sum_{i=0}^{n} \Lambda_{0 i}\left(1-e^{\lambda_{i} T}\right)
$$

Where $C_{\mathrm{i}}$ represents the $i$ element concentration.

Deactivating the sample takes place according to the relation:

$$
\Lambda_{t}=\sum_{i=0}^{n} \Lambda_{0 i} e^{-\lambda_{i}^{T}} c_{i}
$$

where, $\Lambda_{\mathrm{t}}$ is the total specific activity at timet; $\Lambda_{\mathrm{oi}}$ is the initial activity of component, $i$. Counting speed $R$, of the test sample from the radiometric installation is given by the expression:

$$
R=G_{p} \cdot \Lambda_{t} \cdot E_{g} \cdot E_{e}
$$

where $E_{\mathrm{g}}$ is the geometric efficacy of the strain gauge, $E_{\mathrm{e}}$ is a constant, taking into account the detection efficiency, and disintegration scheme; $G_{\mathrm{p}}$ is the weight of the radioactive metal from the wear test sample. Because $E_{\mathrm{g}}$ and $E_{\mathrm{e}}$ are difficult to determine, the option was to use the known standard weights $G_{\mathrm{e}}$ irradiated together with the steel samples.

By establishing, with the help of radiometric device, the counting speed $R_{\mathrm{e}}$ of the standard, it is possible to determine the unknown product $\Lambda_{t} \cdot E_{g} \cdot E_{e}$, from Eq. (4).

From Eq. (4) written for the standard, it results:

$$
G_{e} / R_{e}=1 / \Lambda_{t} \cdot E_{g} \cdot E_{e}=K
$$

The weight of the metal $(G)$ contained in the wear ample will be:

$$
G=K\left(R-R_{f}\right)
$$

Where $R_{\mathrm{f}}$ is the counting speed of radiation background of the room where the measurements were taken and $R$ is the counting speed of the sample's impulses.

\section{RESULTS AND DISCUSSION}

In Table 1 are presented for example wear test results conducted on injection of the four plastics reinforced with SGF, on experimental model of Rp3 steel nozzle (62 HRC $790 \mathrm{HV})$. The results are obtained by gravimetric measurements.

Graphical test results conducted on hardened steel Rp3 (62 HRC) are shown in Fig. 4.

Table - 1: The results of tests carried out on the experimental model made from hardened steel Rp3 (62 HRC) to determine the wear rate of the injection nozzle

\begin{tabular}{|c|c|c|c|c|c|c|}
\hline Mt. & A & B & C & $\begin{array}{c}\text { Mean } \\
\text { gravimetric } \\
\text { wear of } \\
\text { samples } \\
\left(10^{-5} \mathrm{~g}\right)\end{array}$ & $\begin{array}{c}\text { Total wear } \\
\text { volume } \\
\Delta \mathrm{V}_{\mathrm{t}}=\Sigma \Delta \mathrm{V} \\
\left(10^{-4} \mathrm{~cm}^{3}\right)\end{array}$ & $\begin{array}{c}\text { Wear } \\
\text { rate } \\
\left(10^{-8}\right. \\
\left.\mathrm{cm}^{3} / \mathrm{h}\right)\end{array}$ \\
\hline 1 & 0 & 0 & 0 & 0 & 0 & 0 \\
\hline 1 & 25 & 7 & 6 & 2 & 60.61 & 6.11 \\
\hline 1 & 25 & 7 & 6 & 2 & 60.61 & 6.11 \\
\hline 1 & 50 & 7 & 6 & 5 & 151.52 & 15.28 \\
\hline 2 & 0 & 0 & 0 & 0 & 0 & 0 \\
\hline 2 & 230 & 15 & 5 & 8 & 251.96 & 12.1 \\
\hline 2 & 230 & 15 & 5 & 8 & 251.96 & 12.1 \\
\hline 2 & 460 & 15 & 5 & 16 & 503.92 & 24.19 \\
\hline 3 & 0 & 0 & 0 & 0 & 0 & 0 \\
\hline 3 & 230 & 18 & 5 & 6 & 148.14 & 5.59 \\
\hline 3 & 230 & 18 & 5 & 6 & 148.14 & 5.59 \\
\hline 3 & 460 & 18 & 5 & 10 & 296.28 & 11.18 \\
\hline 4 & 0 & 0 & 0 & 0 & 0 & 0 \\
\hline 4 & 230 & 16 & 5 & 17 & 519.61 & 11.34 \\
\hline 4 & 230 & 16 & 5 & 16 & 488.61 & 1067 \\
\hline 4 & 460 & 16 & 5 & 22 & 671.84 & 14.67 \\
\hline
\end{tabular}

1. Maranyl Polyamide $+20 \%$ SGF; 2.Noryl Polyamide + $20 \%$ SGF; 3.Nylonplast AVE Polyamide + $30 \%$ SGF; 4. Lexan Polycarbonate $+20 \%$ SGF; A - volume of the injected material $\left(\mathrm{cm}^{3}\right)$; B - during the filling of the die (s); $\mathrm{C}$ - the average diameter of the nozzle $(\mathrm{mm})$

\section{Rp 3 (62 HRC) experimental nozzle}

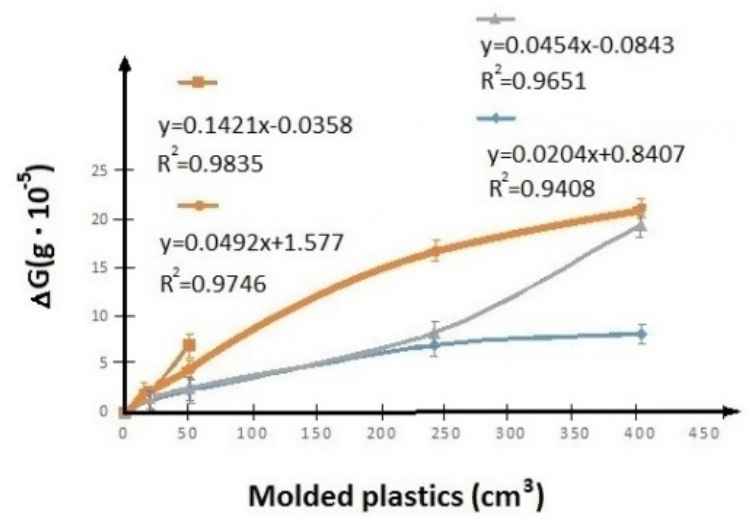

Fig - 4: Wear test results conducted on the four injection plastics reinforced with SGF, on experimental nozzle model of steel Rp 3 (62 HRC 790 HV): a Maranyl Polyamide + 20 \% SGF; • Noryl Polyamide + 20 \% SGF; $\Delta$ Nylonplast AVE Polyamide $+30 \%$ SGF; $\diamond$ Lexan Polycarbonate +20 $\%$ SGF.

In order to simplify the presentation, wear tests results 
carried out with C120 (59 HRC 710 HV) steel, mould nozzle are presented in graphical mode, in Fig. 5.

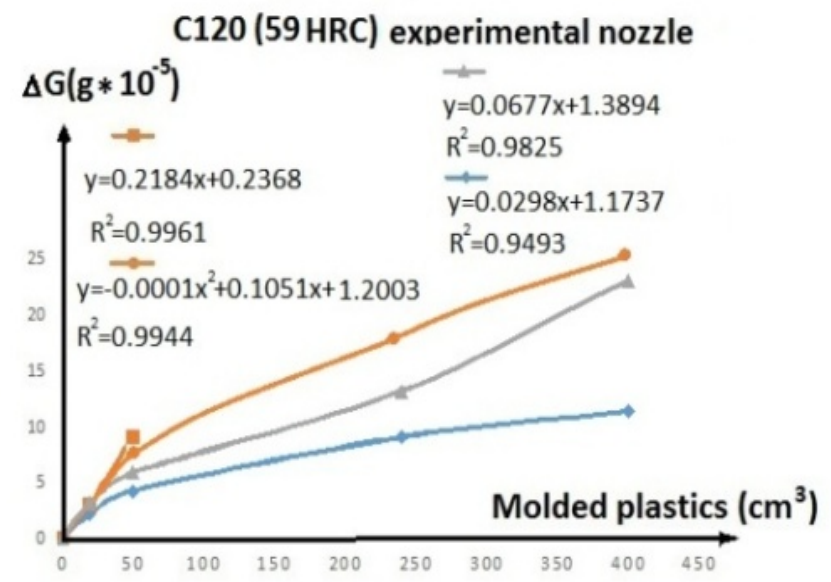

Fig - 5: Wear test results conducted on the four injection plastics reinforced with SGF, on experimental nozzle model of steel C120 (59 HRC 710 HV): a Maranyl Polyamide + 20 \% SGF; • Noryl Polyamide + 20 \% SGF; $\Delta$ Nylonplast AVE Polyamide $+30 \%$ SGF; Lexan Polycarbonate +20 $\%$ SGF.

The comparison of the curves of Figs. 4 and 5, the result is the same wear ranking prodused on the nozzles by injected plastics, with a wear decrease in the case of Rp3 steel nozzle, due to its greater hardness, but the shape of the wear curves indicate the major questions relating to the accuracy of the results.

Thus, the Polyamides with $20 \%$ glass fibre seem to have produced the biggest wear on both steel than Polyamide with $30 \%$ glass fibre, really hard to understand. Since the results related to wear nozzles are of the same order of magnitude $\left(10^{-5} \mathrm{~g}\right)$, it has dropped below of the steel nozzles Rp3, due to its difficult processing.

Next were injected Nylonplast AVE Polyamide $+30 \%$ SGF, Noryl Polyamide $+20 \%$ SGF, Maranyl Polyamide + $20 \%$ SGF and Lexan Polycarbonate $+20 \%$ SGF, through the Rp3 steel nozzles and from C120 steel nozzles, whose wear samples (position 4 in figure 1) were irradiated with a beam of neutrons.

Radioactive metallic wear products were embedded in the molten polymer injected. Radiometric method has been used. From the amount of $460 \mathrm{~cm}^{3}$ polymer injected injected from each plastic material, through each of the two nozzles have been taken a sample of approximately $0.5 \mathrm{~cm}^{3}$, whose radioactivity was assessed in the way described in section "radiometric method".

Eight nozzles were used, four of Rp3 steel and four of C120 steel, with semi-cylindrical samples activated by irradiation. The results of radiometric measurements are shown in Tables 2 and 3.
Table - 2: The radiometric results of the tests carried out on the experimental model made from hardened steel Rp3 (62 HRC) to determine the wear rate of the injection nozzle at injection of $230 \mathrm{~cm}^{3}$ of plastic composite

\begin{tabular}{|l|l|l|l|l|}
\hline $\begin{array}{l}\text { Plastic } \\
\text { materials }\end{array}$ & $\begin{array}{l}\text { Impulses } \\
\text { Counting } \\
\text { Speed } R \\
(\mathrm{imp} / \mathrm{min})\end{array}$ & $\begin{array}{l}\text { Backround } \\
F \\
(\mathrm{imp} / \mathrm{min})\end{array}$ & $\begin{array}{l}R-F \\
(\mathrm{imp} / \mathrm{min})\end{array}$ & $\begin{array}{l}\text { Gravimetric } \\
\text { wear } \\
G=K[R-F] \\
\left(10^{-4} \mathrm{mg}\right)\end{array}$ \\
\hline $\begin{array}{l}\text { Nylonplast } \\
\text { AVE } \\
\begin{array}{l}\text { Polyamide } \\
+30 \% \text { SGF }\end{array}\end{array}$ & 462 & 379 & 83 & 88.792 \\
\hline $\begin{array}{l}\text { Noryl } \\
\text { Polyamide } \\
+20 \% \text { SGF }\end{array}$ & 397 & 378 & 19 & 20.139 \\
\hline $\begin{array}{l}\text { Maranyl } \\
\text { Polyamide } \\
+20 \% \text { SGF }\end{array}$ & 420 & 367 & 43 & 57.228 \\
\hline $\begin{array}{l}\text { Lexan } \\
\text { Polycarbon. } \\
+20 \% \text { SGF }\end{array}$ & 405 & 378 & 27 & 32.852 \\
\hline
\end{tabular}

$G_{\mathrm{e}}=3.92 \mathrm{mg} ; R_{\mathrm{e}}=36989 \mathrm{imp} / \mathrm{min} ; K=G_{\mathrm{e}} / R_{\mathrm{e}}=$ $1.0598 \cdot 10^{-4} \mathrm{mg} \cdot \mathrm{min} / \mathrm{imp}$.

Table - 3: The radiometric results of the tests carried out on the experimental model made from hardened steel C120 (59 $\mathrm{HRC}$ ) to determine the wear rate of the injection nozzle at injection of $230 \mathrm{~cm}^{3}$ of plastic composite

\begin{tabular}{|l|l|l|l|l|}
\hline $\begin{array}{l}\text { Plastic } \\
\text { materials }\end{array}$ & $\begin{array}{l}\text { Impulses } \\
\text { Counting } \\
\text { Speed } R \\
(\mathrm{imp} / \mathrm{min})\end{array}$ & $\begin{array}{l}\text { Backround } \\
F \\
(\mathrm{imp} / \mathrm{min})\end{array}$ & $\begin{array}{l}R-F \\
\text { (imp/min) }\end{array}$ & $\begin{array}{l}\text { Gravimetric } \\
\text { wear } \\
G=K[R-F] \\
\left(10^{-4} \mathrm{mg}\right)\end{array}$ \\
\hline $\begin{array}{l}\text { Nylonplast } \\
\text { AVE } \\
\begin{array}{l}\text { Polyamide } \\
+30 \% \text { SGF }\end{array}\end{array}$ & 504 & 379 & 125 & 133.3088 \\
\hline $\begin{array}{l}\text { Noryl } \\
\text { Polyamide } \\
+20 \% \text { SGF }\end{array}$ & 404 & 378 & 26 & 26.46134 \\
\hline $\begin{array}{l}\text { Maranyl } \\
\text { Polyamide } \\
+20 \% \text { SGF }\end{array}$ & 444 & 367 & 77 & 81.50223 \\
\hline $\begin{array}{l}\text { Lexan } \\
\text { Polycarbon. } \\
+20 \% \text { SGF }\end{array}$ & 421 & 378 & 43 & 47.63115 \\
\hline
\end{tabular}

$G_{\mathrm{e}}=3.92 \mathrm{mg} ; R_{\mathrm{e}}=36989 \mathrm{imp} / \mathrm{min} ; K=G_{\mathrm{e}} / R_{\mathrm{e}}=$ $1.0598 \cdot 10^{-4} \mathrm{mg} \cdot \mathrm{min} / \mathrm{imp}$.

Numerical results in Tables 2 and 3 are shown in figure 6 . As expected, polymer with a higher content of SGF (30\%) leads to a higher wear of steel surfaces, than in the case of polymers with $20 \%$ SGF. Also, it was found that samples of wear is dependent on their surface hardness. As expected, the metallic surfaces of steel Rp3 used were less than those made of $\mathrm{C} 120$ steel, due to their hardness higher.

The other eight nozzles were used, four of Rp3 steel and four of C120 steel, with wear semi - cylindrical wear samples with thin layer coatings of TiN and CrNirradied. Wear samples covered with TiN had micro-hardness 64 HRC (840 HV), and micro-hardness those coated with $\mathrm{CrN}$ 
was 41.3 HRC (900 HV). To avoid cluttering this paper, results of radiometric measurements for the $\mathrm{TiN}$ and $\mathrm{CrN}$ coatings on Rp3 and C120 steel and are presented in Table 4 and Table 5 , respectively.

Table - 4: The radiometric results of the tests carried out on the experimental model made from hardened steel C120 (59 $\mathrm{HRC})$ with TiN coating $(64 \mathrm{HRC} \sim 840 \mathrm{HV})$ to determine the wear rate of the injection nozzle at injection of $230 \mathrm{~cm}^{3}$ of plastic composite

\begin{tabular}{|l|l|l|l|l|}
\hline $\begin{array}{l}\text { Plastic } \\
\text { materials }\end{array}$ & $\begin{array}{l}\text { Impulses } \\
\text { Counting } \\
\text { Speed } R \\
\text { (imp/min) }\end{array}$ & $\begin{array}{l}\text { Backround } \\
F \\
\text { (imp/min) }\end{array}$ & $\begin{array}{l}R-F \\
\text { (imp/min) }\end{array}$ & $\begin{array}{l}\text { Gravimetric } \\
\text { wear } \\
G=K[R-F] \\
\left(10^{-4} \mathrm{mg}\right)\end{array}$ \\
\hline $\begin{array}{l}\text { Nylonplast } \\
\text { AVE } \\
\text { Polyamide } \\
+30 \% \text { SGF }\end{array}$ & 410 & 379 & 31 & 85.792 \\
\hline $\begin{array}{l}\text { Noryl } \\
\text { Polyamide } \\
+20 \% \text { SGF }\end{array}$ & 393 & 363 & 30 & 20.139 \\
\hline $\begin{array}{l}\text { Maranyl } \\
\text { Polyamide } \\
+20 \% \text { SGF }\end{array}$ & 385 & 367 & 18 & 57.228 \\
\hline $\begin{array}{l}\text { Lexan } \\
\text { Polycarbon. } \\
+20 \% \text { SGF }\end{array}$ & 377 & 373 & 4 & 32.854 \\
\hline
\end{tabular}

Table - 5: The radiometric results of the tests carried out on the experimental model made from hardened steel C120 (59 $\mathrm{HRC})$ with $\mathrm{CrN}$ coating $(71.3 \mathrm{HRC} \sim 900 \mathrm{HV})$ to determine the wear rate of the injection nozzle at injection of $230 \mathrm{~cm}^{3}$ of plastic composite

\begin{tabular}{|l|l|l|l|l|}
\hline $\begin{array}{l}\text { Plastic } \\
\text { materials }\end{array}$ & $\begin{array}{l}\text { Impulses } \\
\text { Counting } \\
\text { Speed } R \\
\text { (imp/min) }\end{array}$ & $\begin{array}{l}\text { Backround } \\
\text { (imp/min) }\end{array}$ & $\begin{array}{l}R-F \\
\text { (imp/min) }\end{array}$ & $\begin{array}{l}\text { Gravimetric } \\
\text { wear } \\
G=K[R-F] \\
\left(10^{-4} \mathrm{mg}\right)\end{array}$ \\
\hline $\begin{array}{l}\text { Nylonplast } \\
\text { AVE } \\
\begin{array}{l}\text { Polyamide } \\
+30 \% \text { SGF }\end{array}\end{array}$ & 395 & 380 & 15 & 11.775 \\
\hline $\begin{array}{l}\text { Noryl } \\
\text { Polyamide } \\
+20 \% \text { SGF }\end{array}$ & 373 & 369 & 4 & 4.239 \\
\hline $\begin{array}{l}\text { Maranyl } \\
\text { Polyamide } \\
+20 \% \text { SGF }\end{array}$ & 387 & 378 & 9 & 9.338 \\
\hline $\begin{array}{l}\text { Lexan } \\
\text { Polycarbon. } \\
+20 \% \text { SGF }\end{array}$ & 375 & 374 & 1 & 10.598 \\
\hline
\end{tabular}

Fig. 6 shows the graph of the radiometric of wear test results of thin coatings withTiN and $\mathrm{CrN}$ on the wear of Rp3 steel samples, and Fig. 7 shows the graph of the radiometric of wear test results of thin coatings withTiN and $\mathrm{CrN}$ on the wear of C120 steel samples.

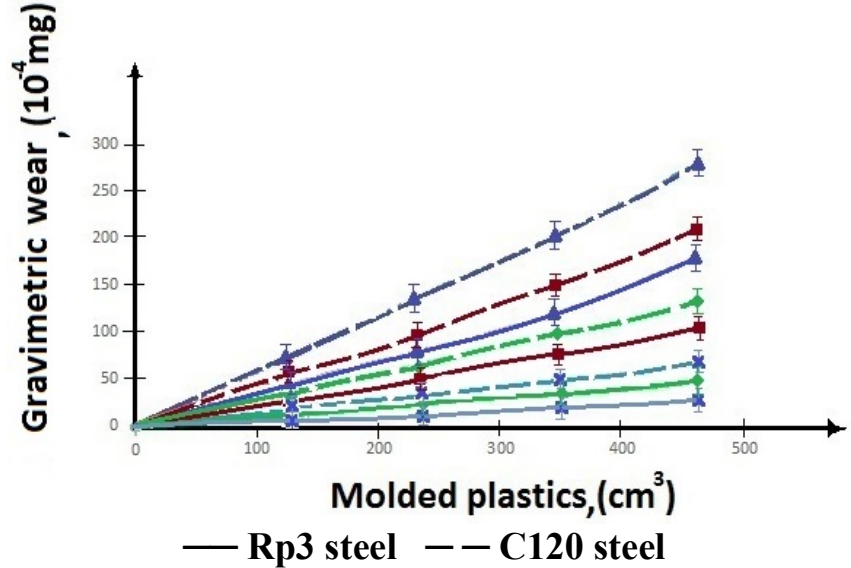

Fig - 6: The radiometric results of tests carried out on the experimental model made from hardened steel Rp3 (62

HRC) - and C120 (59 HRC) - - to determine the wear rate of the injection nozzle at injection of $230 \mathrm{~cm}^{3}$ :

Maranyl Polyamide + $20 \%$ SGF; • Noryl Polyamide +20 $\%$ SGF; $\Delta$ Nylonplast AVE Polyamide + $30 \%$ SGF; Lexan Polycarbonate $+20 \% \mathrm{SGF} . \mathrm{G}_{\mathrm{e}}=3.92 \mathrm{mg} ; \mathrm{R}_{\mathrm{e}}=$ $36989 \mathrm{imp} / \mathrm{min} ; K=G_{\mathrm{e}} / R_{\mathrm{e}}=1.0598 \cdot 10^{-4} \mathrm{mg} \cdot \mathrm{min} / \mathrm{imp}$.

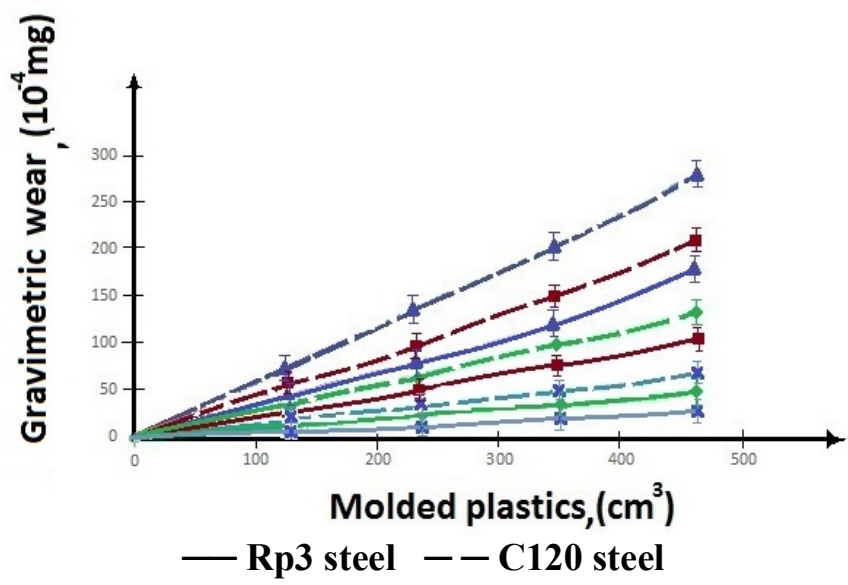

Fig - 7: The radiometric results of tests carried out on the experimental model made from hardened steel C120 (59 HRC) covered with thin coatings of $\mathrm{TiN}-$ and $\mathrm{CrN}--$ coatings, to determine the wear rate of the injection nozzle at injection of $230 \mathrm{~cm}^{3}$ of $\boldsymbol{\Delta}$ Nylonplast AVE Polyamide + 30 \% SGF; - Noryl Polyamide + 20 \% SGF; • Maranyl Polyamide $+20 \%$ SGF; $\diamond$ Lexan Polycarbonate $+20 \%$ SGF.

You may notice that both the coatings TiN and CrN, lead to decreased wear of steel surfaces. Unfortunately, the coating of $\mathrm{CrN}$ on $\mathrm{Rp} 3$ steel presented a clear trend of massive speeling, so that this steel can no longer be taken into consideration for this application. More than likely that this behavior is due to an inappropriate report hardness / Young's module.

Analyzing the results obtained by the radiometric method of intensity compared to those reported by Knappe and Mahler [2], you need to see the same linear weight variation of wear, depending on the amount of plastic material with SGF injected. Values in our research by the radiometric method 
on the C120 steel (similar of DIN steel 1.8550-17007, or of CrAlNi7V-34 after the DIN 17006) coated with TiN, (64 $\mathrm{HRC} \sim 840 \mathrm{HV})$, are relatively similar to those of the wear measured in the Deuschen Kunststoff Institut - DKI in Darmstadt [1].

\section{CONCLUSIONS}

In these respects there are clearly several conclusions. Thus, it is clear that a higher content of SGF of polymer leads to a higher wear of working parts surfaces of processing machines, screws, barrels and molds.

Wear is manifested as an evolutionary process, by adhesion, abrasion and corrosion. In order to ensure the high durability of screws and barrels, it is absolutely necessary the choice of the appropriate base alloys, but also of hard coatings are compatible with ensuring an optimum ratio between hardness and modulus of elasticity of the material.

In this context, the $\mathrm{C} 120$ steel (steel for hot working tools, similar to 1.8550 steel - after DIN 17007, or CrAlNi7V after DIN 17006) covered with TiN, 64 HRC ( 840 HV), presented the best results.

How no is it possible to stop the process of wear, delay its evolution is essential, because the metallic wear particles driven by melted polymer emphasizes evolution process toward catastrophic stage.

\section{ACKNOWLEDGEMENT}

The authors would like to thank their colleagues from the Institute of Solid Mechanics of the Romanian Academy and University of Civil Engineering for your material and logistic support.

\section{REFERENCES}

[1]. H. Dominghaus, ModellversuchezumVerschleiß in Kunststoff verarbeitungs maschinen, Kunststoff Rundschau 18, 8, 1971, 383-389.

[2]. W. Bauer, Verfahren zum Prüfen der Verschleiß wirkung von Preßmassen, Kunststoffe (1967), 53-55.

[3]. W. W. McCandless, u.a, Verschleißfeste und corrosion beständige Zylinder und Schnecken für Kunststoffmaschinen, Industrie - Anzeiger 91 (1969), Nr. 25, S. 25-29.[4]. R. Meridies, u.a,"Verschlei $\beta$ an Schnecken vonSpritzgießmaschinen bri der Verarbeitung von Kunststoffen“,Plastverarbeiter, 21 (1970), 617-623.

[4]. K. Stark,"Undersuschungen über den Verschleiß an Metallöberflächen die mit strömended Kunststoffschmeltzen in Berührung stehen". Student Arbeit am Deuschen Kunststoff - Institut, Darmstadt, 1970.

[5]. L. Capitanu, A. Iarovici, J. Onisoru, “On polyamide and polycarbonate composite materials behaviour under dry friction", The Annals of University " Dunarea de jos" of Galati, Fascicle VIII, Tribology, 2003, 74-80..
[6]. L. Capitanu, A. Iarovici, J. Onisoru,Tribological aspects for injection procerssing of thermoplastic composite materials with glass fiber", Journal of the Balkan Tribological Association, Vol.11, No.4, 542-557 (2006); ISSN 1310-4772.

[7]. L. Capitanu, V. Florescu,"Tribological Aspects of Wear of Polished Steel Surfaces in Dry Friction Contact on Polymer Composites with Glass Fibres", American Journal of Materials Science 2013, 3(1): 8-18. DOI: 10.5923/j.materials.20130301.02.

[8]. L. Capitanu, D. Rus, L-L. Badita, "The Wear reaction of steel in injection of certain polymers filled with glass fibres", World Academy of Sience, Engineering and Technology” 83 (2013), 628-635. pISSN 2010-376X, eISSN 2010-3778.

[9]. L. Capitanu, L-L. Badita,V. Florescu,D.Rus, “Aspects of the influence of hardness on the dry friction coefficient at a timken type couple, plastic reinforced with glass fibers/steel", Journal of Tribology and Surface Engineering,Volume 3. Issue 1-2, 95-108. 2013. ISSN: 1949-4866.

[9]. Maranyl Polyamide, Technical Note, Goodfelow Cambridge Ltd., 2012.

[10]. V. Viers, D. Brendt, Polymer Data Handbook. Oxford University Press, Inc. (1999). p. 189. ISBN 9780195107890.

[11]. Material Selection Guide, 1.888. CURBELL, www.curbellplastics.com

[12]. Lexan, Polycarbonate Resin, General Electric Data Sheet, www.vistatek.com.

[13]. Makrolon ${ }^{\circledR}$ polycarbonate product description,Bayer A.G. www.plastics.bayer.com

[14]. Technyl, Rhone Paulenc, https://www.google.ro/\#q $=$ Technyl $\% 2 \mathrm{C}+$ Rhone + Paulenc.

[15]. W. Knappe, W. D. Mahler, Modellversuche zum Verschleiß in Kunststoffverarbeitungsmaschinen. Kunststoff Rundschau 19, 2/3, 1972, pp. 45-51.

\section{BIOGRAPHIES}

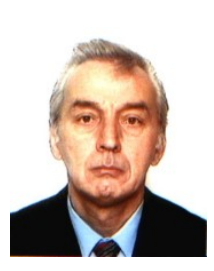

Lucian Capitanu: Working for 44 years in scientific research in the area of tribology and biotribology. He has published over 400 research papers and 6 monographs. Is a founding member of the Romanian Association of Tribology (ART) and member of the Balkan Tribology Association (BTA). Since 2000 he is Professor and Scientific Director of the Institute of Solid Mechanics of Romanian Academy.

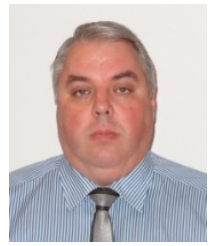

Virgil Florescu: He graduated from the Polytechnic Institute of Bucharest, is Ph.d. in engineering sciences. He has worked in academic scientific research and currently is Director of the Mech. Eng. Department of the Institute of Civil Engineering from Bucharest. He has published over 200 scientific papers, is author of 4 monographs and has participated in many international conferences in the field of "tribology". 
Liliana-Laura Badita: She graduated the Faculty of Physics of the University of Bucharest, Ph.d. in engineering sciences. Is researcher at National Institute of Research -Development in Mechatronics \& Measurement Technique from Bucharest, and specializes in investigating the properties of coatings and nano - coatings with thin layers and biotribology. Is the author of over 250 scientific works and has participated in numerous international collaborations. 